\title{
Droit naturel: relancer l'histoire?, sous la direction de Louis-Léon Christians, François Coppens, Xavier Dijon, Paul Favraux, Gaëlle Fiasse, Jean-Michel Longneaux et Muriel Ruol., avec une préface de Catherine Labrusse et une postface de Jean-Marc Ferry, Collection: „Droit et Religion” 2, Bruylant, Bruxelles 2008, 735 stron.
}

Jest to druga z cyklu „Prawo i Religia” praca zbiorowa ponad dwudziestu autorów, wydana w Belgii, w języku francuskim. Na czele komitetu redakcyjnego stoi profesor prawa wyznaniowego Uniwersytetu Katolickiego w Louvain - Louis-Léon Christians. Podkreśla on interdyscyplinarny charakter kolekcji będącej owocem badań nad prawem pozostającym w związku z takimi dyscyplinami, jak: socjoantropologia, filozofia, psychologia, nauki polityczne, czy teologia (str. 5). Głównym problemem badań niniejszej publikacji jest tytułowe prawo naturalne. Autorzy pytają o to, czym właściwie jest to prawo, co wniosło do historii i jak było wykorzystywane oraz co może nam jeszcze przynieść (str. 13). Choć w przeszłości różni myśliciele szukali odpowiedzi na powyższe pytania, to według nich należy stawiać je również obecnie. Szczególnie zagadnienie prawa naturalnego w aspekcie istoty ludzkiej żyjącej w świecie współczesnym, a zwłaszcza ustroju demokratycznym (str. 13).

W powyższym kontekście autorzy szukają zasad postępowania, w szczególności prawodawstwa, dla którego sprawiedliwość to nie tylko to, co zostało wyrażone w kodeksie. Mają się wspólnie dowiedzieć, jak słuszność wyraża się w tych zasadach, które nie są samowolne i narzuca się je całemu prawodawstwu. Gdzie szukać ich uprawomocnienia, zwłaszcza gdy historia odmówiła tego zgodzie powszechnej, tradycji, geniuszowi ludzkiemu, decyzji, determinizmowi społecznemu, naukom (humanistycznym i ścisłym), wartościom, idealnej wspólnocie, rozumowi, religii..., ale dlaczego nie naturze? (str. 14).

Aby odnaleźć odpowiedź na to ostatnie i najważniejsze według nich pytanie, we Wprowadzeniu stawiają siedem kolejnych szczegółowych pytań, na podstawie których tworzą swój naukowy projekt (str. 15-18). Po pierwsze, pytają o naturę, do której odnosi się prawo. Historia myśli prawnonaturalnej jest przecież równie złożona i skomplikowana jak sama natura. W rozważaniach na jej temat nawet najznakomitsi myśliciele bardzo się od siebie różnią. Jednak w celu poznania ich poglądów na temat prawa naturalnego trzeba najpierw zrozumieć pojęcie natury. Po drugie, autorzy pytają o to, kto wyraża prawo naturalne, jakie są zalety tej kompetencji i jej warunki? Po trzecie, jaki zachodzi stosunek w przypadku wyrażania prawa naturalnego, czy ma ono jakieś zewnętrzne (transcendentne) - boskie pochodzenie? Po czwarte, czy prawo naturalne jest uniwersalne? Po piąte, czy jest trwałe (a zatem czy jest zmienne, czy może niezmienne)? Po szóste, jaka 
jest treść prawa naturalnego? I wreszcie po siódme, jaką rolę odgrywa prawo naturalne w stosunku do społeczeństwa, które się do niego odwołuje?

Powyższe pytania szczegółowe mają zagwarantować jedność niniejszego projektu, którego struktura wewnętrzna została podzielona na trzy części: pierwsza zatytułowana Grand angle (str. 23-97) poświęcona jest 25 wiekom historii myśli filozoficznej i prawnej na temat prawa naturalnego. Stanowi ona swoisty zarys dziejów odwoływania się do prawa naturalnego od starożytności po wiek XX; zaprezentował ją Xavier Dijon. Część druga, nosząca łaciński tytuł: Focus (ogień, ognisko), jest zbiorem 15 tekstów różnych specjalistów, którzy prezentują poglądy na temat prawa natury jakiegoś konkretnego myśliciela. Poszczególne teksty, choć nienumerowane, to jednak ułożone są chronologicznie. Zbiór rozpoczyna rozdział, w którym Bradley Lewis z Katolickiego Uniwersytetu Amerykańskiego dokonuje analizy głównie Praw Platona, ale także jego dialogów poruszających problematykę polityczno-prawną, jak np. Państwo, Gorgiasz, Minos (str. 101-132). Następny rozdział - Gaëlle’a Fiasse z Uniwersytetu McGill w Montrealu - poświęcony jest prawu naturalnemu, celowości, naturze oraz niewolnictwu u Arystotelesa (str.133-155). Z kolei Xavier Marquez i Walter Nicgorski z Uniwersytetu Notre Dame w Indianie omawiają prawo natury i naturę prawa w myśli politycznej Cycerona (str. 157-191). Następnie Philippe Curbelié z Instytutu Katolickiego w Tuluzie omawia prawo naturalne według Świętego Augustyna (str.193-214). Dalej Thérèse-Anne Druart z Katolickiego Uniwersytetu Amerykańskiego charakteryzuje poglądy etyki uniwersalnej Al-Fârâbîego, zwanego także Abunaserem, żyjącego na przełomie IX i X wieku (str. 215-232). W kolejnym rozdziale Joseph E. David ze School of Law Uniwersytetu Nowojorskiego omawia poglądy na naturę i prawo innego arabskiego uczonego - Mojżesza Majmonidesa, żyjącego w latach 1135-1204 (str. 233-255). Autorem fragmentu poświęconego prawu naturalnemu w myśli Świętego Tomasza z Akwinu jest trzeci już przedstawiciel Katolickiego Uniwersytetu Amerykańskiego - David J. Klassen (str. 257-291). Catherine Larrère z paryskiej Sorbony omawia poglądy Hugona Grocjusza na prawo naturalne i towarzyskość (str. 293-329). Autorka w interesujący sposób nawiązuje przy

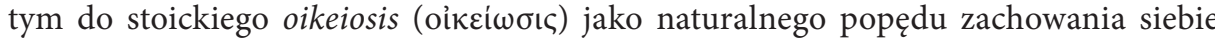
oraz teorii racjonalizacji prawa Monteskiusza. Arash Abizadeh z Uniwersytetu McGill w Montrealu w swojej części pracy porusza problematykę prawa natury u Tomasza Hobbesa (str. 331-378). Ian Harris z Uniwersytetu w Leicester omawia poglądy prawnonaturalne Johna Locke’a, porównując je w dużym stopniu z poglądami Hobbesa (str. 379-429). Następnie Thomas Berns z Centrum Filozofii Prawa Wolnego Uniwersytetu w Brukseli porusza zagadnienie gwarancji absolutnej prawa naturalnego u Spinozy jako prawa do swobodnego myślenia (str. 431-452). Ghislain Waterlot z Uniwersytetu w Genewie dotyka problematyki interpretacyjnej myśli politycznej Jana Jakuba Rousseau w związku z jego poglądami na temat prawa natury. Zastanawia się, czy Rousseau odnawia, czy też odchodzi od koncepcji prawa naturalnego (str. 453-475). Ostatnie trzy fragmenty tej części pracy wiążą się z przedstawicielami idealizmu niemieckie- 
go i ich poglądami dotyczącymi prawa natury. Najpierw Henri D’Aviau de Ternay z jezuickiego Centre Sèvres w Paryżu charakteryzuje stanowisko Kanta (str. 477-507). Drugim omawianym przedstawicielem idealizmu niemieckiego jest Johann Gottlieb Fichte. W rozdziale mu poświęconym Jean-Christophe Merle z uniwersytetów w Tours i Saarbrücken omawia podstawę prawa natury u Fichtego (str. 509-539). Część drugą zamykają rozważania Filipa Souala z Uniwersytetu w Poitiers, a dotyczące kwestii prawa natury i prawa rozumowego według Hegla (str. 541-569).

Jak widać, autorzy kończą swoje rozważania tej części pracy na ostatnim przedstawicielu filozofii nowożytnej. Omawiają raczej poglądy klasycznych i najbardziej znanych myślicieli zajmujących się problematyką prawa naturalnego. Każdy z nich zamyka swój fragment wskazówkami bibliograficznymi. Autorzy odwołują się do tekstów źródłowych opisywanych filozofów oraz opracowań, głównie w języku angielskim, francuskim, niemieckim i włoskim. Trudno doszukać się akcentów polskich związanych z tytułowym prawem naturalnym. W indeksie autorów jest zaledwie kilka nazwisk brzmiących po polsku, wskazujących jedynie na ich polskie pochodzenie, np. Jean Starobinski ${ }^{1}$, Jacob Rogozinski², Robert Sokolowski ${ }^{3}$ i współautor jednego ze wskazanych wyżej tekstów Walter Nicgorski. Nie ma mowy o najbardziej znanym polskim filozofie prawa Leonie Petrażyckim, mimo iż wspomina się trzykrotnie nazwisko niemieckiego neokantysty $\mathrm{z}$ tego samego okresu, a związanego z teorią prawa natury o zmiennej treści, czyli Rudolfa Stammlera. Tłumaczy to w pewien sposób fakt nieomawiania przez autorów myśli XX-wiecznej, a więc także Gustawa Radbrucha. Szkoda, że przy tekście o Janie Jakubie Rousseau nie ma odwołań do prac uczonego związanego także z Polską, tj. Bronisława Baczki, zajmującego się właśnie w Szwajcarii myślą tego genewskiego myśliciela ${ }^{4}$.

Trzecia część projektu zatytułowana Contre-Jours składa się z czterech rozdziałów, których autorzy poruszają także zagadnienia współczesnej filozofii prawa. W pierwszym z nich François Coppens z Wyższej Szkoły Henan w belgijskim Namur zastanawia się nad tym, czy powinniśmy patrzeć na prawo naturalne ze sceptycyzmem? W swoich rozważaniach na ten temat odwołuje się do poglądów wspomnia-

1 Jean Starobinski jest szwajcarskim filozofem, profesorem Uniwersytetu w Genewie, a także członkiem Académie des Sciences Morales et Politiques oraz Institut de France.

2 Jacob Rogozinski jest profesorem filozofii Uniwersytetu Marca Blocha w Strasburgu.

3 Robert Sokolowski jest filozofem związanym głównie z Katolickim Uniwersytetem Amerykańskim (The Catolic University of America), swoje prace pisze przede wszystkim w języku angielskim i francuskim.

4 Bronisław Baczko od 1974 r. związany jest z Uniwersytetem Genewskim, którego jest również profesorem honorowym. Zob. jego francuskojęzyczne prace dotyczące Jana Jakuba Rousseau: Rousseau, solitude et communauté, traduit du polonais par Claire Brendhel-Lamhout, Paris 1974; Rousseau et l'aliénation Sociale, en: Annales de la Société J. J. Rousseau, vol. XXXV (1959-1962), s. 223-237; Rousseau et la pédagogie révolutionnaire, en: M. Hobson; T. T. A. Leigh; R. Wokler, Rousseau $\&$ the eighteenth century: essays in memory of R.A. Leigh. Oxford: The Voltaire Foundation, 1992. 
nych już w części drugiej projektu arabskich uczonych - Al-Fârâbîego i Majmonidesa oraz średniowiecznego myśliciela włoskiego Marsyliusza z Padwy (str. 573-600). W rozdziale drugim noszącym tytuł Teologiczny skręt prawa naturalnego ponownie do głosu dochodzi Xavier Dijon. Jego teksty, w tym z części pierwszej, stanowią najobszerniejsze fragmenty całego projektu. Jednak w tym miejscu autor podejmuje problematykę prawa naturalnego w ujęciu teologicznym i to nie tylko chrześcijańskim (katolickim czy protestanckim), ale także z perspektywy teologicznej wierzeń politeistycznych oraz judaizmu i islamu. Szczególnie interesujące wydają się jego rozważania dotyczące stanu natury, umowy społecznej oraz demokracji, zwłaszcza jej świeckiego i absolutnego obecnie charakteru (str. 637-659). W rozdziale trzecim Paul Favraux z Facultés Universitaires N.-D. de la Paix w Namur zajmuje się prawem naturalnym, przede wszystkim jako ideą. Zastanawia się przy tym nad odchodzeniem od idei prawa naturalnego, jak również nad jej kontynuacją. W ostatnim, czwartym rozdziale tej części, Jean-Michel Longneaux również z Facultés Universitaires N.-D. de la Paix w Namur ujmuje $\mathrm{z}$ kolei prawo naturalne $\mathrm{w}$ doświadczeniu fenomenologicznym (str. 683-698). Wyjaśniając znaczenie metody fenomenologicznej dochodzi do wniosku, że szeroko rozumiana nauka nie jest w stanie poznać w sposób obiektywny natury ludzkiej. W związku z tym proponuje patrzeć na prawo naturalne jako przejaw życia, w którym każdy człowiek nosi w sobie takiego człowieka, jakim być powinien. W ten sposób ontologia fenomenologiczna jest zarazem według niego etyką. Całość zamyka posłowie Jeana-Marca Ferry, który zastanawia się nad prawem naturalnym jako historią w poszukiwaniu czystej normatywności (str. 699-708).

Jak zauważyła w Przedmowie emerytowana już profesor paryskiej Sorbony Catherine Labrusse-Riou, niniejsza praca adresowana jest przede wszystkim do tych prawników, którzy wykładają na uniwersytetach, pracują w sądach, są adwokatami, pracownikami administracji i przedsiębiorstw, a w szczególności politykami zajmującymi się tworzeniem prawa. Z pewnością dla prawników praktyków i dogmatyków prawo naturalne, podobnie jak ta księga, stanowi owoc refleksji filozoficznej. Potwierdza to również fakt, iż o wiele bardziej jest ona wyrazem głosu filozofów niż prawników, którym wydaje się, że filozofia nie jest potrzebna w ich zawodzie. Choć większość współczesnych specjalistów prawa zadowala się prawem pozytywnym, które jest coraz bardziej złożone, wyspecjalizowane, zmienne, to jednak ryzykuje - jej zdaniem - wykluczeniem z dogłębnego zrozumienia swojej dyscypliny (str. 7). Autorka ubolewa nad tym, że we Francji filozofią i teorią prawa zainteresowanych jest coraz mniej studentów. Wydaje się, że z bardzo podobną sytuacją mamy do czynienia również w Polsce. Jednakże według niej wydziały prawa poza Francją kontynuują nauczanie studentów w duchu kultury prawnej swojej długiej historii, która pomaga im zrozumieć jak i dlaczego zadaniem prawa jest rozwiązywanie problemów praktycznych (str. 7-8). Niniejsze dzieło ma zatem przyczynić się do wzbogacenia i utrzymania praktyki prawnej, która nie może zrezygnować ani z realizmu prawa 
pozytywnego, ani też z krytyki wywodzącej się z filozofii prawa naturalnego (str. 11). Być może powinniśmy poszukać nowego określenia dla prawa naturalnego pozostającego „w kręgu mitów”, w stosunku do których rozum ma zdolność rozróżniania i oddzielania mitów destrukcyjnych. W powyższym kontekście jej konkluzję można sprowadzić do tego, iż sprawiedliwość jest nieosiągalna, ale przynajmniej można określić i nazwać zło - znoszone i zadawane przez ludzi, na które remedium zawsze stanowiło prawo (str. 11).

Karol Kuźmicz

5 Zob. J. Jabłoński-Bonca, Prawo w kręgu mitów, Gdańsk 1995. 